\title{
Chemical Analysis of an Edible African Termite, Macrotermes nigeriensis; a Potential Antidote to Food Security Problem
}

Igwe CU*, Ujowundu CO, Nwaogu LA and Okwu GN

Department of Biochemistry, Federal University of Technology, Owerri, Nigeria

\begin{abstract}
Macrotermes nigeriensis is a gregarious termite that is eaten as a delicacy in different parts of Nigeria and several other African countries. The concentrations of proximate, minerals, vitamins and fatty acids of the termite were determined using standard methods. The following major nutrients were identified: proteins $(20.94 \pm 0.08 \%)$, carbohydrates $(20.74 \pm 0.00 \%)$ and lipids (34.23 $\pm 0.83 \%)$; the minerals included potassium (3360.00 $\mathrm{mg} / \mathrm{kg})$, sodium $(1120.00 \mathrm{mg} / \mathrm{kg})$, iron $(9.56 \mathrm{mg} / \mathrm{kg})$ and zinc $(0.97 \mathrm{mg} / \mathrm{kg})$; the vitamins were ascorbic acid $(17.76 \pm 1.60 \mathrm{mg} / 100 \mathrm{~g})$, niacin $(2.74 \pm 0.02 \mathrm{mg} / 100 \mathrm{~g})$ and riboflavin $(1.56 \pm 0.02 \mathrm{mg} / 100 \mathrm{~g})$; and the fatty acids were oleic acid $(52.45 \pm 0.58 \%)$, palmitic acid $(31.39 \pm 0.92 \%)$ and linoleic acid $(7.57 \pm 0.16 \%)$. The high fat content of the termite was made up mainly of unsaturated fatty acids (60.64\%), consisting of $53.07 \%$ monounsaturated and $7.57 \%$ of polyunsaturated fatty acids. These results indicate that this delicacy is a potentially rich source of nutrients, vitamins, minerals and unsaturated fatty acids that may be necessary for combating protein energy related disease conditions prevalent in developing countries of the world.
\end{abstract}

Keywords: Termite; Fatty acids; Nutrition; Insects

\section{Introduction}

In Nigeria, the food situation is worsening owing to increasing population and restrictions on the importation of food among several other factors. This has resulted in a high incidence of hunger and malnutrition; a situation in which children and women, are most vulnerable. Apart from the incidence of hunger posed by the worsening food situation, the widespread prevalence of protein energy malnutrition (PEM) has resulted in high morbidity and mortality rates especially among infants and children in developing countries including Nigeria. While every measure is being taken to boost food production by conventional agriculture, including current interest focused on the possibilities of exploring the vast numbers of less familiar plant resources existing in the wild [1], almost zero interest has been shown to the consumption of insects, a traditionally recognized and available source of protein and fats. Furthermore, protein foods are in short supply, and thus not within the reach of low-income households who unfortunately form the major part of the population of most developing economies [2]. The insufficient availability of common animal protein sources, and the high cost of the few available plant protein sources, should as a matter of urgency prompt an intense research into the possible exploitation of the nutrient potentials of insects, especially the popular African termites.

Edible insects have served as traditionally and nutritionally important food for Africans, Asians, Australians and Latin Americans for many years [3]. Insects are high in protein, energy (calories) and various vitamins and minerals [3,4]. Recently, there has been an upsurge of interest in the use of insects as food, may be because many are nutritionally, economically and ecologically important [5]. Furthermore, entomophagy has gained prominence in recent years as a result of drought and poor economic conditions. It may have undoubtedly played an important role in reducing Kwashiorkor among young children of poor parents. Ademolekun [6] had earlier reported that because of the high cost of conventional protein foods, protein energy malnutrition is widespread in rural Nigeria. Studies have showed that most Nigerians have had direct or indirect experience with entomophagy, although it is more prevalent in the rural than urbanized areas. Large quantities of insects, especially grasshoppers, caterpillars and termites are brought from rural areas for sale in urban markets [6].

Macrotermes nigeriensis is a winged adult termite of the order, Isoptera and family, termitidae. Although, $M$. nigeriensis is an eusocial insect with a typical colony containing nymphs (semi-mature young), workers, soldiers and the reproductive individuals (alates) of both genders. The alates are the winged adults that are commonly caught and consumed. They are the fully developed adult stage of the termites. There exist fair variations among the winged adults, probably due to geographical locations or developmental stages. There are many species of termites such as $M$. nigeriensis, $M$. notalensis, $M$. subhylinus or M. belicosus. However, they are all simply termed 'termites', 'winged termites' or 'Macrotermes species' [7,8]. The winged termites are known locally in various parts of Nigeria by different names such as 'aku' in Ibo, 'chinge' in Hausa and 'Esusu' in Yoruba [9]. M. nigeriensis is enjoyed in all parts of Nigeria, especially because it is present at the onset of the rainy season when livestock is lean, new crops have not yet produced food, and store produced from previous growing season is running low. Early in the rainy season, the alates fly off from their nest in large numbers in their 'nuptial flight'. During this flight, pairs of male and female alates isolate themselves from the others and fall to the ground. Their wings break off and each pair goes its own way to form a nest in a suitable spot, where they become the potential king and queen. During the flight, they are usually attracted to sources of illumination and are harvested by women and children by placing a bowl of water

*Corresponding author: Igwe CU, Department of Biochemistry, Federal University of Technology, Owerri, Nigeria, Tel: +234-806-6075-587; E-mail: igwechidi@yahoo. com

Received November 18, 2011; Accepted December 14, 2011; Published December 16, 2011

Citation: Igwe CU, Ujowundu CO, Nwaogu LA, Okwu GN (2011) Chemical Analysis of an Edible African Termite, Macrotermes nigeriensis; a Potential Antidote to Food Security Problem. Biochem \& Anal Biochem 1:105. doi:10.4172/21611009.1000105

Copyright: (C) 2011 Igwe CU, et al. This is an open-access article distributed under the terms of the Creative Commons Attribution License, which permits unrestricted use, distribution, and reproduction in any medium, provided the original author and source are credited. 
under a light source. In most parts of Nigeria, M. nigeriensis is sold in open market after being well prepared by washing, salting to taste and mild frying or roasting. It can also be consumed raw. It has a nutty flavor when prepared. Oil is not usually needed during frying, since their bodies are naturally rich in oil. The delicious taste of termite makes them a good meal for all groups. Fried termite meal is also suitable to the European palate [5].

Notwithstanding the increasing interest in entomophagy and the popularity of $M$. nigeriensis as a delicacy in Nigeria and beyond, not much work has been done on the nutritional benefits derivable from its consumption. The present study was undertaken to provide data on the proximate, microelemental, macroelemental, vitamins and fatty acids compositions of this important termite delicacy, and to draw inferences on its possible use to combat protein energy deficiency related problems.

\section{Materials and Methods}

\section{Sample collection and processing}

Adult Macrotermes nigeriensis were collected in the early morning hours of July 2011, from residential buildings in and around Federal University of Technology, Owerri, Nigeria. They were washed, dewinged, oven-dried at $40^{\circ} \mathrm{C}$ to a constant weight, and then ground into fine powder using a hand mill. The processed termite sample was packaged in labeled dry glass jar and stored at $4^{\circ} \mathrm{C}$ until analysis [10].

\section{Proximate analysis}

Crude fat was extracted by the soxhlet method with petroleum ether $\left(40-60^{\circ} \mathrm{C}\right)$ for $8 \mathrm{~h}$ and determined by gravimetric method. Crude protein content was determined by the microjeldahl method using a nitrogen protein conversion factor of 6.25. These, as well as carbohydrate, crude fiber, ash and moisture contents were determined by standard methods as described by [11].

\section{Analysis for minerals}

A portion, $2 \mathrm{~g}$ of the ground sample was incinerated in a muffle furnace at $600^{\circ} \mathrm{C}$ for $3 \mathrm{~h}$. The ash obtained was cooled, dissolved in $5 \mathrm{ml}$ of $6 \mathrm{~N} \mathrm{HCl}$ and allowed to stand for $30 \mathrm{~min}$. It was later filtered and its volume made up to $50 \mathrm{ml}$ with deionized water. The resulting extract was used for the determination of sodium, potassium, iron, calcium, magnesium, manganese, zinc, copper, chromium, cobalt and selenium by the use of an atomic absorption spectrophotometer (Alpha 4, Chem. Tech. Analytical, England). Standard solutions (Sigma Chemicals, USA) of each of the minerals were also prepared and co-analyzed with the sample extract preparations. Phosphorous was determined as phosphate by the Vanadomolybdate colorimetric method [12]. The standard phosphate stock solution was prepared by dissolving $2.1935 \mathrm{~g}$ of pure potassium dihydrogen phosphate in $500 \mathrm{ml}$ of water, diluted and co-analyzed with the sample extract.

\section{Analysis for vitamins}

Vitamins A and C contents of the sample were co-determined with crystalline vitamin A alcohol and ascorbic acid standards (obtained from Distillation Products Industries, N.Y.) using the methods described by [13]. The sample was analyzed for the B-complex vitamins (thiamine, riboflavin and niacin) with the aid of Skalar Analyzer 918 Solar Model (FISON, England) using methods described by [11], along with thiamine hydrochloride, riboflavin and niacin reference standard solution (Sigma Chemicals, USA)

\section{Fatty acids analyses}

The oil in a portion, $5 \mathrm{~g}$ of the ground sample was extracted for $8 \mathrm{~h}$ with $20 \mathrm{ml}$ of $1 \mathrm{~N}$ hexane. Then $0.8 \mathrm{~g}$ of the extracted oil was saponified for $1 \mathrm{~h}$ with $15 \mathrm{ml}$ of $\mathrm{KOH}$ in methanol at $90^{\circ} \mathrm{C}$, treated with $2 \mathrm{ml}$ of $1.4 \mathrm{~N} \mathrm{HCl}$ for another $1 \mathrm{~h}$ and allowed to cool to room temperature. To the cooled solution, $15 \mathrm{ml}$ of $\mathrm{N}$-heptane and $200 \mathrm{ml}$ of brine were added, mixed thoroughly and $5 \mu \mathrm{l}$ of the fatty acid methyl esters (FAMEs) solution was analyzed with the aid of a High Performance Gas Chromatography system (Hewlet, USA) for the fatty acids content. The FAMEs extract was co-analyzed with authentic FAME standards (Sigma Chemicals, USA) of known structures.

\section{Results}

The quantitative estimations (in percentages) of the proximate compositions of $M$. nigeriensis are shown in Table 1 . The termite sample contains relatively high contents of lipid $(34.23 \pm 0.83 \%)$, protein (20.94 $\pm 0.08 \%)$ and carbohydrate $(20.74 \pm 0.00 \%)$. The moisture, ash and crude fibre contents were $10.78 \pm 0.02 \%, 7.60 \pm 0.327 \%$ and $5.71 \pm$ $0.01 \%$ respectively.

Table 2 shows the macro- and micro-elemental compositions of $M$. nigeriensis. The sample has high concentrations of potassium $(3360 \mathrm{mg} /$ $\mathrm{kg})$, sodium (1120 mg/kg), magnesium $(60.96 \mathrm{mg} / \mathrm{kg})$ and iron $(9.56$ $\mathrm{mg} / \mathrm{kg})$, with low contents of calcium $(1.00 \mathrm{mg} / \mathrm{kg})$, a macroelement, and selenium $(0.04 \mathrm{mg} / \mathrm{kg})$, a microelement.

Results of the vitamins analyses (Table 3) of $M$. nigeriensis showed that the termite contains relatively low contents of vitamin A $(0.35 \pm$ $0.00 \mathrm{mg} / 100 \mathrm{~g})$, riboflavin $(0.67 \pm 0.04 \mathrm{mg} / 100 \mathrm{~g})$, thiamine $(1.56 \pm 0.02$ $\mathrm{mg} / 100 \mathrm{~g})$ and niacin $(2.74 \pm 0.02 \mathrm{mg} / 100 \mathrm{~g})$, but with an appreciable amount of vitamin C $(17.76 \pm 1.79 \mathrm{mg} / 100 \mathrm{~g})$.

\begin{tabular}{|l|l|}
\hline Nutrient & Composition (\%) \\
\hline Protein & $20.94 \pm 0.08$ \\
\hline Lipid & $34.23 \pm 0.83$ \\
\hline Ash & $7.60 \pm 0.33$ \\
\hline Moisture & $10.78 \pm 0.02$ \\
\hline Crude fibre & $5.71 \pm 0.01$ \\
\hline Carbohydrate & $20.74 \pm 0.00$ \\
\hline
\end{tabular}

Values are mean \pm standard deviation of triplicate determination.

Table 1: The Proximate Composition of Macrotermes nigeriensis Sample.

\begin{tabular}{|l|l|}
\hline Minerals & Composition $(\mathbf{m g} / \mathbf{k g}$ dry weight) \\
\hline Macroelements & \\
\hline Calcium & 1.00 \\
\hline Phosphorus & 14.90 \\
\hline Magnesium & 60.96 \\
\hline Potassium & 3360.00 \\
\hline Sodium & 1120.00 \\
\hline Microelements & \\
\hline Cobalt & 0.20 \\
\hline Selenium & 0.04 \\
\hline Chromium & 0.25 \\
\hline Copper & 0.72 \\
\hline Iron & 9.56 \\
\hline Zinc & 0.97 \\
\hline Manganese & 0.81 \\
\hline
\end{tabular}

Values are mean of duplicate determinations.

Table 2: Elemental Compositions of Macrotermes nigeriensis Sample. 
Table 4 shows the fatty acid profile and the degree of saturation of lipid content of $M$. nigeriensis. Oleic acid (C18:1) was found to be the fatty acid with the highest percentage composition $(52.45 \pm 0.58 \%)$ in the sample, while lauric acid (C12:0) was the least at $0.20 \pm 0.03 \%$. The total composition of unsaturated fatty acids was more (60.64\%) compared to that of total saturated fatty acid (39.36\%). Among the unsaturated fatty acids, the monounsaturated fatty acids (MUFA) content (53.07\%) was over $700 \%$ more than the polyunsaturated fatty acids (PUFA) content (7.57\%) of the termite sample. Palmitic acid (C16:0) has the highest percentage composition ( $31.39 \pm 0.92 \%)$ among the detected saturated fatty acids in the sample, while oleic acid (C18:1) had the highest percentage composition ( $52.45 \pm 0.58 \%$ ) among unsaturated fatty acids.

\section{Discussion}

In Africa, entomophagy is traditionally and culturally acceptable way by which low income persons supplement the meager protein content of their high carbohydrate diets [14]. M. nigeriensis is a gregarious insect and a highly relished food item in Nigeria, especially among the rural populace but is also currently available in most urban markets of the country.

The lipid content of the termite is appreciably high in comparison with the reported mean lipid content of $20 \%$ for most adult insects on a dry weight basis [15]. Our observation is in agreement with reported oil content of $28.37 \pm 0.00 \%$ for $M$. nigeriensis [8], $22.5 \%$ for M. notalensis [16], and $28.2 \%$ [16] and $36.12 \pm 0.28 \%$ [17] for M. bellicosus. The lipid content we obtained, along with those mentioned above, are however lower than a lipid value of $46.1 \%$ (moisture free basis) earlier reported for M. bellicosus [18]. Dietary fats increase the palatability of food by absorbing and retaining flavor. Hence, the high lipid content observed in this termite could have contributed to its highly acceptable flavor when fried or roasted, and may contribute to the reduced need of oil in the preparation of its delicacy.

The crude protein content we observed for M. nigeriensis was higher

\begin{tabular}{|l|l|}
\hline Vitamins & Composition $\mathbf{( m g / 1 0 0 g )}$ \\
\hline Vitamin A & $0.35 \pm 0.00$ \\
\hline Vitamin C & $17.76 \pm 1.60$ \\
\hline Riboflavin & $1.56 \pm 0.02$ \\
\hline Thiamin & $0.67 \pm 0.04$ \\
\hline Niacin & $2.74 \pm 0.02$ \\
\hline
\end{tabular}

Values are mean \pm standard deviation of triplicate determinations.

Table 3: Vitamins Composition of Macrotermes nigeriensis Sample.

\begin{tabular}{|l|l|}
\hline Fatty Acid Profile & Composition (\%) \\
\hline Lauric acid (C12:0) & $0.20 \pm 0.03$ \\
\hline Myristic (C14:0) & $0.62 \pm 0.06$ \\
\hline Palmitic acid (C16:0) & $31.39 \pm 0.92$ \\
\hline Palmitoleic acid (C16:1) & $0.62 \pm 0.02$ \\
\hline Stearic acid (C18:0) & $7.14 \pm 0.29$ \\
\hline Oleic acid (C18:1) & $52.45 \pm 0.58$ \\
\hline Linoleic acid (C18:2) & $7.57 \pm 0.16$ \\
\hline Degree of Saturation & \\
\hline Total unsaturated fatty acid (TUFA) & 60.64 \\
\hline - Monounsaturated fatty acid (MUFA) & 53.07 \\
\hline - Polyunsaturated fatty acid (PUFA) & 7.57 \\
\hline Total saturated fatty acid (TSFA) & 39.35 \\
\hline
\end{tabular}

Fatty acid profile values are mean \pm standard deviation of triplicate determinations.

Table 4: The Fatty Acid Profile And The Degree of Saturation of Macrotermes nigeriensis Oil Sample. than the $14.2 \%$ reported for M. subhyalinus [5], but quantitatively comparable with $20.4 \%$ and $22.1 \%$ reported for M. bellicosus and $M$. notalensis respectively [16]. The result indicates that the termite is a good source of protein for man and animals. Meanwhile, an adult male of about $70 \mathrm{~kg}$ body weight requires $35 \mathrm{~g}$ of protein daily. Therefore, only about $209 \mathrm{~g}$ of the termite delicacy would be required to provide an average adult man's minimum daily protein need, with an allowance of $25 \%$ made for indigestibility and the limiting sulphur amino acid content [19]. Thus, a small amount of the delicacy needs to be consumed per day, especially for children, to meet the requirement.

The results of this study also showed that the termite has an appreciable content of carbohydrate $(20.74 \pm 0.00 \%)$. However, the carbohydrate content observed is low in comparison with those reported for M. bellicosus (43.3\%) and M. notalensis (42.8\%) [16]. Given the observed high lipids, protein and carbohydrate contents of this termite, it could be inferred that the delicacy, if adequately promoted, can help in controlling protein energy malnutrition, an imbalance between the supply of protein and energy, and the body's demand for them to ensure optimal growth and function, which is currently ravaging children in developing countries [20].

As observed, the termite has a fair content of ash $(7.60 \pm 0.33 \%)$, with the major macrominerals being potassium and sodium, while the microminerals were iron, zinc, manganese and cupper. Minerals are known to play important metabolic and physiologic roles in the living system. Iron, zinc, selenium, cupper and manganese strengthen the immune system as antioxidant enzyme cofactors [21]. Similarly, magnesium, zinc and selenium prevent cardiomyopathy, muscle degeneration, growth retardation, impaired spermatogenesis, immunologic dysfunction and bleeding disorder [22].

The vitamin contents (Table 3 ) of $M$. nigeriensis showed that it contained appreciably high amounts of vitamins $\mathrm{C}, \mathrm{B}_{2}$ (riboflavin), $\mathrm{B}_{3}$ (niacin) and $\mathrm{B}_{1}$ (thiamine) and $\mathrm{A}$. The results indicate that the $M$. nigeriensis has higher contents of vitamins $\mathrm{C}(17.76 \pm 1.60 \mathrm{mg} / 100 \mathrm{~g})$ and $\mathrm{A}(350 \mu \mathrm{g} / 100 \mathrm{~g})$ in comparison with $3.41 \mathrm{mg} / 100 \mathrm{~g}$ and $2.89 \mu \mathrm{g} / 100 \mathrm{~g}$ for $M$. bellicosus, and $3.01 \mathrm{mg} / 100 \mathrm{~g}$ and $2.56 \mu \mathrm{g} / 100 \mathrm{~g}$ for $M$. notalensis respectively [16]. Vitamin C maintains blood vessels flexibility and improves circulation in the arteries of people including smokers. The one of most important benefit derivable from vitamins $\mathrm{A}$ and $\mathrm{C}$ is their role as antioxidants, oxygen free radical scavengers, while that of the B-vitamins is their role as co-enzymes in several enzyme systems of the body. The high vitamins and minerals contents present the termite as a highly potential, good source of food supplement for malnourished people and animals.

M. nigeriensis is rich in oleic acid, palmitic acid and linoleic acid, an essential fatty acid, but poor in myristic acid, lauric acid and palmitoleic acid. These observations are in agreement with the reports on $M$. bellicosus [17], and other insect species [15]. The total saturated fatty acid content of the termite is $39.35 \%$, while that of the unsaturated fatty acids is $60.64 \%$, with monosaturated fatty acids (MUFA) comprising $53.07 \%$ and polyunsaturated fatty acids (PUFA) making up $7.57 \%$ only. Saturated fatty acids are not good for human consumption because they have been implicated in certain cardiovascular disorders such as atherosclerosis, cancer and aging [23]. Low saturated fatty acid content makes M. nigeriensis an important food component for those who have high blood cholesterol content, and may be at risk of cardiovascular disease. A diet providing 1-2\% of its caloric energy as fats has been reported to be sufficient for human consumption [23]. Thus, the high fatty acids content of this termite portends risk for its consumers. However, this may not be the case since over $60 \%$ of the fatty acids 
Citation: Igwe CU, Ujowundu CO, Nwaogu LA, Okwu GN (2011) Chemical Analysis of an Edible African Termite, Macrotermes nigeriensis; a Potential Antidote to Food Security Problem. Biochem \& Anal Biochem 1:105. doi:10.4172/2161-1009.1000105

present in the termite are in the form of highly desirable unsaturated fatty acids. Furthermore, we had earlier reported that intake of different levels of $M$. nigeriensis based diet increases serum HDL, improves positive atherogenic risk index with concomitant reduction in serum LDL concentration and the negative atherogenic risk index [10]. In addition, the termite delicacy is prepared by the use of reduced oilfrying or roasting methods, which are local de-fating processes. The implication is a delicacy with markedly increased relative proportions of the other nutrients, already identified in appreciable quantities in the termite. This may translate to greatly increased protein, carbohydrate, vitamin and mineral contents.

In conclusion, the study has revealed $M$. nigeriensis as a very good source of nutrients, vitamins, minerals and unsaturated fatty acids, especially proteins and carbohydrate necessary for combating protein energy malnutrition rampant in our world today.

\section{References}

1. Ojiako OA, Igwe CU (2008) The nutritive, anti-nutritive and hepatotoxic properties of Trichosanthes anguina (Snake Tomato) fruits from Nigeria. Pak J Nutr 7: 85-89.

2. Ojiako OA, Igwe CU, Agha NC, Ogbuji CA, Onwuliri VA (2010) Protein and Amino acid compositions of Sphenostylis stenocarpa, Sesamum indicum Monodora myristica and Afzelia africana seeds from Nigeria. Pak J Nutr 9: 368-372.

3. Allotey J, Mpuchane SF (2003) Utilization of useful insect as food source. Afri J Food Agric Nutri \& Development 2: 160-168

4. Motshegwe SM, Holmback J, Yeboah SO (1998) General Properties and Fatty Acid Composition of the Oil from the Mopane Caterpillar, Imbresia belina. J Amer Oil Chem Soc 75: 725-728.

5. Defoliart RG (1989) The Human use of Insects as Human Food and as Anima Feed. Bulletin of Entomological Society of America 35: 22-35.

6. Ademolekun B (1993) Epidemiological studies of the etiology of a seasonal ataxia in Nigeria. Neurobiology 43: 14-19.

7. Banjo AD, Lawal OA, Olubanjo OA, Owolana OA (2004) Ethno-zoological Knowledge and Perception of the Value of Insects among the ljebus (South Western Nigeria). Global J Pure Applied Sci 10: 1-6.
8. Mbah CE, Elekima GOV (2007) Nutrient composition of some terrestrial insects in Ahmadu Bello University, Samaru Zaria, Nigeria. Science World J. 2: 17-20.

9. Fasoranti JO, Ajiboye DO (1993) Some edible insects of Kwara State, Nigeria Amer Entomol 39: 113-116.

10. Igwe CU, Onwuliri VA, Ojiako AO, Arukwe U (2011) Effects of Macrotermes nigeriensis Based Diet on Hepatic and Serum Lipids of Albino Rats. Australian J Basic \& Appl Scs 5: 906-910

11. AOAC (1990) Official Methods of Analysis of the Association of Analytical Chemists, Washington D.C.

12. Pearson D (1976) The Chemical Analysis of Food. Churchill Livingstone, Edinburgh.

13. Ojiako OA, Akubugwo El (1997) An Introductory Approach to Practica Biochemistry. CRC Publishers, Nigeria.

14. Ekpo KE, Onigbinde AO, Asia IO (2009) Pharmaceutical Potentials of the Oils of some Popular Insects Consumed in Southern Nigeria. Afri J Pharm \& Pharmacol 3: 051-057.

15. Fast PG (1970) Insect Lipids. Progress in the Chemistry of Fats and other Lipids, 11: 181-242.

16. Banjo AD, Lawal OA, Songonuga EA (2006) The Nutritional Value of Fourteen Species of Edible Insects in Southwestern Nigeria. Afri J Biotech 5: 298-301.

17. Ekpo KE, Onigbinde AO (2007) Characterization of lipids in winged reproductives of the termite Macrotermes bellicosus. Pak J Nutr 6: 247-251.

18. Ukhun ME, Osasona MA (1985) Aspects of the Nutrition Chemistry of Macrotermes bellicosus. Nutri Rep Int. 32: 1121-1129.

19. Fagbemi TN, Oshodi AA (1991) Chemical Composition and Functional Properties of Full Fat Fluted Pumpkin Seed Flour. Nig Food J. 9: 26-32.

20. Okwu GN, Ilobinso AC, Onoh CN, Igwe CU (2010) Assessment of Protein Energy Malnutrition Among Preschool Children Attending Well Baby Clinic at Federal Medical Centre, Owerri. Intl J Biochem 2: 77-81.

21. Talwar GP, Srivastava LM, Mudgil KD (1989) Textbook of Biochemistry and Human Biology. Prentice Hall of India Private Limited, India.

22. Chaturvedi VC, Shrivastava R, Upreti RK (2004) Viral Infections and Trace Elements: A complex Interaction. Current Sci 87: 1536-1554.

23. Anita BS, Akpan EJ, Okon PA, Umoren IU (2006) Nutritive and Anti-nutritive Evaluation of Sweet Potatoes Leaf. Pak J Nutri 5: 166-168. 